\title{
ALSÓVÉGTAG-AMPUTÁLT CUKORBETEGEK A REZILIENCIA TÜKRÉBEN
}

\section{MAKAI GÁBOR ${ }^{1}$ - BANDI SZABOLCS ${ }^{2}$ - KISS ENIKÓ CSILLA ${ }^{2}$}

\author{
${ }^{1}$ Magyar Honvédség Egészségügyi Központ, Rehabilitációs Intézet \\ ${ }^{2}$ Pécsi Tudományegyetem, Pszichológia Intézet \\ E-mail: makai18@gmail.com
}

Benyújtva: 2019. szeptember 17. - Elfogadva: 2020. április 26.

\begin{abstract}
Háttér és célok: Az amputáció egy olyan átélt trauma, amely gyökeresen átalakítja az egyén önmagáról és a külvilágról alkotott képét. Jelen vizsgálat célja az volt, hogy megvizsgáljuk, az amputáción átesett betegek milyen pszichés, szociális és fizikai nehézségekkel találják szembe magukat a mütétet követốen, valamint hogyan igyekeznek megküzdeni a kritikus élethelyzettel. A reziliencia nézôpontjából azt kerestük, melyek azok a protektív és rizikótényezók, amelyek szerepet játszanak az alkalmazkodóképesség és a betegek mentális egészségének megörzésében.

Módszer: Alsóvégtag-amputált diabetes mellitusban szenvedō betegeket $(n=46)$ vizsgáltunk utánkövetéssel az amputációt követô elsố, illetve hatodik hónapban, a kutatócsoportunk által összeállított kérdốvcsomag segítségével. Kontrollcsoportként egészséges vizsgálati személyeket vontunk be $(n=63)$, valamint 2-es típusú cukorbetegeket $(n=54)$. A kérdốivcsomag tartalmazta a Beck Depresszió Kérdốvet (BDI-R), a ConnorDavidson Reziliencia Skálát (CD-RISC), a Társas Támogatás Kérdôivet (MOS-SSS), a Pozitív és Negatív Affektivitás Skálát (PANAS), valamint a Folkman és Lazarus-féle Konfliktusmegoldó Kérdốvet (WOC). Eredmények: Az amputációt követô hatodik hónapban a depresszió, valamint a negatív érzelmek mértéke szignifikáns csökkenést mutat, de a depresszió és a negatív érzelmek jelenléte az alkalmazkodás sikerességét veszélyezteti. Ezzel együtt a reziliencia és a pozitív érzelmek dominanciája növekszik. A társas támogatás keresése, különösképpen a betegek pozitív szociális interakción alapuló támasz iránti igénye nô az idô elôrehaladtával, mindez pozitív kapcsolatban áll a rezilienciával. Továbbá protektív tényezóként van jelen a céltudatos cselekvés és az alkalmazkodás mint megküzdési stratégiák, de a negatív érzelmek jelenléte gyengíti a betegek adaptív megküzdését.
\end{abstract}

Következtetések: A magasabb rezilienciával rendelkezô betegek alkalmazkodása sikeresebb, mint azoké, akik negatív alkalmazkodási stratégiákat alkalmaznak.

Kulcsszavak: reziliencia, alsóvégtag-amputált cukorbetegek, depresszió, szorongás, megküzdés, protektív és veszélyeztetô tényezók 


\section{BEVEZETÉS}

Az amputáció egy szerv vagy testrész sebészeti úton történô eltávolítása, aminek a hátterében traumás (baleset) vagy nem traumás eredetú (érszúkület, cukorbetegség, lágyrészinfekció, daganat) okok állnak. Amputációt akkor végeznek, ha ez az egyedüli lehetôség a beteg életének megmentésére, illetve ha a károsodott testrész megtartása egyértelmúen hátrányt jelent (Mayer és Pénzesné, 2002). Magyarországon évente 6500-7000 csonkító mútétet végeznek, ezen belül nagyrészt az alsóvégtagi lokalizáció figyelhetô meg. Az esetek többségében artériás érszúkület következtében kialakuló perifériás érelzáródás, illetve diabetes mellitus szövődménye indokolja a beavatkozást. Hazánkban a nem traumás amputációk közel 29\%-át cukorbetegség miatt hajtják végre, ami éves szinten 3-4000 lábamputációt jelent (Kullman, Belicza és László, 1997; Till, 2010). A diabeteses betegeknél rizikótényezô a diabetes fennállásának ideje, a magasabb éhgyomri vércukor és a HgbA1c (a vizsgálati személy vércukorszintjének, a vércukormérést megelôzô 3 havi átlagát mutatja meg), valamint az előrehaladott stádiumot jelzố retino- és neuropathia (Regöly-Mérei, 2002). Az amputáció a férfiak körében gyakoribb, azonban a nôk legtöbbször súlyosabb tünetekkel és rosszabb prognózissal kerülnek az alapellátásba a férfi páciensekhez képest (Bhuvanesvar, Epstein és Stern, 2007).

\section{Az alkalmazkodás folyamata az amputációt követôen}

A végtag-amputáció számos fizikai, pszichés és társas kihívás elé állítja a pácienst, hiszen változás megy végbe az egyén életében: a szomatikus funkciók károsodnak, testi fájdalom jelenik meg, a protetizálhatóság kérdéssé válik a személy számára, munkahelyen vagy családon belüli változások várnak rá, valamint megváltozik a testkép, énkép is (Panyi és Lábadi, 2015). Ezek a stresszorok jelentôs kihívás elé állítják az egyént, nagy eltérés jelenik meg abban, hogy az alkalmazkodás folyamatában kik azok, akik az amputációt követôen képesek visszanyerni érzelmi, pszichés egyensúlyukat vagy éppen maladaptív reakciót mutatnak, illetve gyengébb minôségú alkalmazkodás jön létre. A változás az állapotukban irreverzibilis, az amputált beteg a csonkolás hatására sérülékennyé válik, mozgása korlátozott lesz. A nem traumás amputációra kerülô betegek számos súlyos alapbetegségben szenvednek már a csonkolást megelôzôen is, a legtöbb esetben a carotis, illetve a koronária-rendszer érintett. Mindezt figyelembe kell venni a beteg rehabilitációja során, hiszen a diabetes rendszerint előrehaladott stádiumban van (Regöly-Mérei, 2002). Az amputációt követôen a betegek nagy része meglévônek érzi az elveszített végtagot vagy végtagrészt, ezt nevezzük fantomjelenségnek, mely a testtudat és testséma eltérésének jellemzó példája (Mayer és Pénzesné, 2002). Emellett komoly fájdalom is megjelenik a betegek 5-10\%-ánál. Ennek következtében nemcsak az amputáció, hanem a csonkfájdalom is jelentôsen befolyásolja a személyek pszichés jóllétét. Az énidentitás döntô részévé a fájdalomséma válik, amely érzelmi distressz, szorongás és depresszió kialakulásával járhat (Nikolajsen és Lindvig, 2001).

A csonkoláshoz való alkalmazkodás olyan folyamat, amelynek része a protézis elfogadása, ami magában foglalja a testképben és énképben bekövetkezett változásokat, 
míg ennek hárítása megnehezíti az új élethelyzethez való alkalmazkodást (Murray és Fox, 2002). Gyakori a szégyen, a bûntudat megjelenése, aminek hátterében a szociális megbélyegzés internalizációja áll. Mindezek ellenére óriási egyéni különbségek figyelhetôk meg a páciens saját megváltozott testéhez való viszonyulásában - van, aki enyhébb szorongásos és depresszív tünetet tapasztal, míg mások nem találják a helyüket, a szorongás lebénítja ôket, pszichésen megdermednek. Egyesek szélsôségesen negatív énképet, kilátástalan jövôképet alakítanak ki (Rybarczyk, Nyenhuis, Nicholas, Cash és Kaiser, 1995). Az alkalmazkodás folyamatát pozitívan segíti elố a társas kapcsolatok és támogatás megléte. A barátok, testvérek, hozzátartozók jótékony hatással vannak a sikeres adaptációra, csökken a stressz, szorongás, melyet a megváltozott állapot okoz. Ezzel szemben a csekély társas támogatás depresszív tünetekkel és csökkent életminôséggel jár együtt, különösen az idôsek körében (Berkman, 1995).

A csonk leplezése képes csökkenteni a szégyen, kényelmetlenség érzését, a protézis viselésével jobban érzik magukat a betegek. Fokozza a zavar érzését, ha mások előtt nem tudják elrejteni a csonkolt végtagot, aminek következtében kerülik a nyilvánosságot, így védekezve a feltételezett elutasítástól. A pozitívabb testkép összefüggésben áll az alkalmazkodás pozitív kimenetével, valamint a protézis elfogadásával (Murray és Fox, 2002). Pereira, Kour, Leow és Pho (1996) hangsúlyozzák, hogy a protézis nemcsak visszaállítja a közel normális megjelenést, de a sérült testképet is helyreállítja. Ezzel szemben Washington (2013) szerint az amputáltaknál a testkép olyan mértékben sérül, hogy azt a protézis nem tudja kompenzálni. Racy (1989) eredményei szerint az a beteg, aki nehezebben fogadja el a megváltozott testképét, hajlamosabb elutasítani a protézis használatát. Ezenkívül a férfiaknál a testképzavar és a protézissel való funkcionális elégedettség negatívan korrelál, a nôknél pedig a testképzavar a protézissel való elégedettség minden aspektusával (funkcionális, esztétikai és súllyal kapcsolatos elégedettség) negatívan korrelál. Ez azt jelenti, hogy a nôk minél kevésbé elégedettek a protézissel, annál negatívabb testképpel rendelkeznek, elégedettségükben pedig a múvégtag használhatóságán kívül fontos szempont annak megjelenése és súlya is (Murray és Fox, 2002).

A csonkolást követôen az alkalmazkodás folyamatát az is nehezíti, hogy a diabetes mellitusból fakadóan végtagamputált betegeknek korábban a cukorbetegség diagnózisával is meg kellett küzdeniük. A krónikus betegség diagnosztizálását követôen a betegek kezdenek másképpen viszonyulni a változásokhoz és a kezelésekhez, amelyek a betegséggel járnak. A krónikus betegséggel élôk kimondottan sebezhetônek érzik magukat (De Ridder, Geenen, Kuijer és Middendorp, 2008), az érzelmek széles spektrumát tapasztalják meg, mint például a szorongást, a rémületet, a tagadást, a depreszsziót vagy éppen a kiszolgáltatottság, a frusztráció vagy a szégyen érzéseit (Pollin és Golant, 1994). Ahogy a krónikus betegség kezdi korlátozni és megváltoztatni az egyén hétköznapjait, a betegek megtapasztalják az egészség elvesztése miatti gyász érzését is (Walsh, 2006).

A szokványostól eltérô gyászreakciókat, a gyász feldolgozásában való megrekedést vagy annak elmaradását komplikált gyásznak nevezzük (Wolfelt, 1991). A 90-es évek közepétôl egyre inkább elôtérbe került az az igény, hogy a komplikált gyász fogalomköre, kritériumai egységesek legyenek, hiszen a klinikai gyakorlatban ez jelentôsen elôsegítené ennek felismerését és megfelelő kezelését. A gyász normál idôtartamára 
nézve általános szabály nem állítható fel. A gyász rendkívül intenzív tünetei 1-3 hónapon belül ugyan általában mérséklôdnek, az átdolgozás és az adaptáció pszichés folyamatai azonban ennél jóval hosszabb ideig tarthatnak (Horowitz, 1993). Az elhúzódó gyászreakció idôbeliségére vonatkozóan a kutatók a hat hónapot javasolják, azaz a diagnózis nem állítható fel addig, amíg fél év el nem telik a veszteséget követốen (Horowitz, Siegel, Holen, Bonanno, Milbrath és Stinson, 1997; Prigerson, 2005; Prigerson, Horowitz, Jacobs, Parkes és Aslan, 2009). A gyászreakció megjelenése az egészség elvesztésével kapcsolatban is megjelenik.

A fentieket összefoglalva az amputáció komoly trauma az egyén életében, amely kihatással van a beteg pszichés múködésére, teljes identitására. A végtag-amputáció olyan fizikai, pszichés és egzisztenciális kihívás elé állítja az egyént, mint például a testi funkciók károsodása, protézishasználat, fizikai fájdalom, munkahelyi vagy munkaköri változások (Crawford, 2002). Az alkalmazkodás folyamata során a betegeknek meg kell küzdeniük a felmerülő testi és lelki problémákkal, újra kell tanulniuk mindennapi aktivitásaik kivitelezését, el kell fogadniuk a testképükben bekövetkezett változásokat és mindezt beépíteni egy új szelfkoncepcióba. Ahhoz, hogy a beteg adaptálódjon az új helyzethez - megküzdjön a veszteség élményével és a felmerülő nehézségekkel -, akaraterôre és kitartásra van szüksége. Továbbá a végtagamputált személyek rehabilitációja során kiemelt fontosságú a pszichológiai tényezôk és a motivációs bázis számbavétele a sikeres felépülés és alkalmazkodás elérése érdekében (Panyi és Lábadi, 2015).

\section{Depresszív és szorongásos tünetek hullámzása}

A végtag-amputáció során a pácienst fizikai és pszichés veszteség éri, így testképében és énképében lényeges változás jön létre. Kutatási eredményeikben a szerzôk leírták, hogy különbözô pszichológiai változók (mint például szociális diszkomfort, megküzdési stratégiák, depresszió, szorongás), valamint környezeti jellemzốk (észlelt és aktuális támogatottság) hatással vannak az alkalmazkodás folyamatára (Livneh, Antonak és Gerhardt, 2000). Számos kutatás középpontjában az amputációt követő depreszszív és szorongásos tünetek vizsgálata áll. Azt találták, hogy a depresszió tünetei összefüggenek a csökkent protézishasználattal, az alacsonyabb aktivitásszinttel és egészségérzettel, valamint súlyosabb distresszel és alvászavarokkal jár együtt (Price és Fisher, 2002). Az életkor tekintetében az idősebbek erôteljesebb tüneteket mutatnak, mint a fiatalok, és ezzel együtt az elsô két évben a depresszió relatíve magasabb szintje figyelhetô meg. A hangulatzavar mellett a szorongás szintjének a változását is vizsgálva kirajzolódott, hogy a szorongás intenzitása nô az amputáció utáni rövid távú idôszakban, majd átlagosan egy év után a szorongásos tünetek megléte az átlag populáció szintjére csökken (Horgan és MacLachlan, 2004). A keresztmetszeti vizsgálatok felmérései alapján a depresszió és a szorongás tünetei háromszor gyakoribbak az amputált betegek körében, mint azon páciensek esetében, akik más ok miatt kerülnek rehabilitációs osztályra. Továbbá azon amputált betegek, akik súlyosabb depresszív és szorongásos tünetet mutatnak, a többi amputált pácienshez képest több idôt töltenek 
az amputációs-rehabilitációs osztályokon (Rajiv Hunter és Alistair, 2007). Horgan és MacLachlan (2004) longitudinális vizsgálata hasonlóképpen megerôsíti a depresszió és a szorongás jelenlétét a csonkolást követôen, azonban az eredmények azt mutatják, hogy a depressziós és szorongásos tünetegyüttes mértéke gyorsan csökken az elsô néhány hónapban. Bhuvanesvar és mtsai (2007) ezt a jelenséget elsôsorban azzal magyarázzák, hogy a beteg a kezdeti sokk és szembesülés után a rehabilitációs osztály védettséget adó keretein belül elkezd alkalmazkodni az új helyzethez. A biztonságot és védelmet adó környezet részben támogatja a megküzdést, de ezzel együtt a valósággal való szembenézéstôl is távol tarthatja a pácienst. A szembesülés, valamint a szorongásos, depresszív tünetegyüttes a rehabilitációs folyamat azon szakaszában erôsödik fel újra, amikor a beteg elôször hagyja el a rehabilitációs osztályt és tapasztalja meg a vele történt változások mértékét és terhét a hétköznapi életben.

A depresszió és szorongás tünetei fokozatosan csökkennek a megváltozott helyzethez való alkalmazkodás következtében, azonban az alkalmazkodás folyamatában nagy egyéni különbségeket figyelhetünk meg. Mindezzel együtt a hosszmetszeti vizsgálatok szerint a tünetek újra felerôsödnek az amputációt követô második évben, ami leginkább a fiatalok körében jellemzô. Ez azzal magyarázható, hogy míg az idôsebbek kevesebb céllal és elvárással kerülnek vissza a hétköznapi életbe, addig a fiatalok esetében sokkal nagyobb a szakadék a realitás és a vágyak között, számukra sokkal nehezebb az állapot elfogadása és az amputáció következményeivel való megküzdés (Singh és mtsai, 2009; Feeney, 2001). A közlemény a szorongás és a depresszió szerepét abban az értelemben emeli ki, hogy a túlzott stressz és a depresszív hangulat meghatározza az amputált beteg fájdalomérzetét, hiszen növeli a fájdalomra való érzékenységet és csökkenti a fájdalomküszöböt, miközben a fájdalom egy olyan stresszor, melynek körkörös következménye lehet a depresszív tünetek további felerôsödése. Emellett magasabb mértékú szorongással és depresszióval bír az a beteg, akinél a csonkfájdalom korlátozza az aktivitást, és nincsen jelen a beteg életében társas támasz (Williamson, 1998). Hawamdeh, Othman és Ibrahim (2008) magasabb mértékú depresszióval és szorongással hozták összefüggésbe az olyan tényezôket, mint a nôi nem, a szociális támogatottság hiánya, a munkanélküliség vagy alacsony jövedelem, a kevesebb eltelt idô az amputáció óta, a traumás amputáció és a térd alatti csonkolás. Míg a térd feletti amputáltak esetében kisebb mértékú depresszióról számolnak be a vizsgálatok, addig a térd alatti mútétek után súlyosabb mértékú depresszió alakul ki. Különös, hogy noha a térd feletti csonkolás mértéke nagyobb, mégis a depresszió szintje alacsonyabb, ami azzal magyarázható, hogy a betegek elhárító mechanizmusai erôsebbek, feltehetôen azáltal, hogy kevésbé viszonyítják magukat az ép végtaggal rendelkezô társaikhoz. A vizsgálatok sokszínúségét mutatja, hogy a depresszió nem mindig velejárója az amputációnak, vagy ahogy az előbbi vizsgálatban látjuk, az egyén hárítása nagymértékben befolyásolhatja a kapott eredményeket (Robinson és mtsai, 2004). Fisher és Hanspal (1998) amputált betegeket vizsgálva például azt találták, hogy a depresszió prevalenciája alacsony volt, és ezzel együtt érzelmi stresszról kevesen számoltak be az amputációt követôen. 


\section{Rezilienciakutatások az alsóvégtag-amputált cukorbetegek körében}

Kevés kutatás helyezi fókuszba a diabetes mellitus szövôdménye miatt alsóvégtag-amputált betegek vizsgálatát, miközben az utóbbi évtizedben hazánkban és világszerte is nố a csonkolások száma (Coffey, Gallagher és Horgan, 2009; Fosse és mtsai, 2009; Till, 2010; Bennett, 2016).

Az amputációt követôen nagy egyéni különbségek figyelhetook meg az amputációra adott testi és pszichés reakciók tekintetében, azonban vannak olyan pszichés válaszreakciók, amelyek szinte minden páciensnél jelentkeznek. Ezek közül jellemzó reakció a már említett szorongás, a depresszió érzése, a szociális helyzetekben fellépô nehézségek, a csökkent életminôség és a gyászreakció (Eisner, Darlington, Stride és Grimer, 2001; Desmond és MacLachlan, 2002). A pszichés válaszreakciót emellett befolyásolja az életkor, a nem, a társas támogatást nyújtó szociális háló, az egyén személyiségtényezői és megküzdôképessége, továbbá a fantomszenzációk, a fájdalom fellépése, valamint az amputáció oka és a beavatkozás óta eltelt idő. Mindezen tényezôk a rehabilitáció során szerepet játszanak a betegek megváltozott élethelyzethez történô alkalmazkodásában (Horgan és MacLachlan, 2004).

McDonald, Sharpe és Blaszczynski (2014) megerôsítik azon kutatási eredményeket, amelyek azt igazolták, hogy az amputáción átesett betegek szignifikánsan súlyosabb depresszív tüneteket mutatnak, mint más cukorbetegek, akiknél nem történt csonkolás, valamint az amputáció hatással van a fizikai aktivitás csökkenésére, az életminôség romlására, a negatív testkép kialakulására és a betegek adaptációjára. Továbbá azt találták, hogy nemcsak önmagában az amputáció következményének tekinthetô a csökkent életminóség érzése, a szociális nehézségek, a testképpel való elégedetlenség vagy a depresszió magas értéke, hanem olyan tényezók is szerepet játszanak ebben, mint a beteg életkörülménye, korábbi és késôbbi fizikai betegsége, az amputáció utáni komplikációk, az orvosi beavatkozások, valamint az életkor és a nem. A szerzók továbbá hangsúlyozzák, hogy korábban kevés olyan vizsgálat történt, amely a pszichés válaszreakció mellett a szociális tényezôkre fókuszált volna, a korábbi kutatások elsôsorban a depresszió és a szorongás meglétét vagy annak hiányát állították vizsgálatuk középpontjába (Carrington, Mawdsley, Kincey, Boulton, 1996; Peters és mtsai, 2001; Willrich, Pinzur, McNeil, Juknelis és Lavery, 2005; Boutoille, Feraille, Maulaz és Krempf, 2008).

Price és Fisher (2002) megerôsítik, hogy a kutatások fókuszában tehát nem csak a pszichológiai változók állnak (depresszió mértéke, megküzdési stratégiák), hanem annak vizsgálata is, hogy a beteg milyen szociális környezetben tud megküzdeni az ôt ért változásokkal, biztonságban érzi-e magát, támogatott-e, vagy épp ellenkezóleg. A társas kapcsolatok és a támogatás jelenléte vagy annak hiánya már az amputációt követôen nagy jelentôségú. Bebizonyosodott az is, hogy ha lehetôség van rá, a frissen amputált személy más amputáltakkal keresi a kapcsolatot, beszélget, tapasztalatot cserél. A társas támogatás jótékony hatással van a mentális egészség megôrzésére azáltal, hogy csökkenti a stresszt és a szorongást. A csekély társas támogatás viszont csökkent életminôséggel, több depresszív tünettel jár együtt, különösképpen az idôsebbek körében (Price és Fisher, 2000; Horgan és MacLachan, 2004). Fokozottan veszélyeztetettek azok a páciensek, akik visszahúzódnak, és kerülik a társas érintkezést (Berkman, 
1995). Az elkerülô stratégiához sorolhatók azok a reakciók is, amelyek lehetnek adaptívak, mint például az olvasás, zenehallgatás. Sok esetben a beteg a kívülálló számára aktívnak tûnik, azonban a valóságban nem néz szembe a problémával, és inkább visszavonul (Livneh és mtsai, 2000). A maladaptív stratégiák jellemzôje, hogy rontják a betegek fizikai és pszichés jóllétét, ami szorongáshoz és további fizikai vagy pszichés tünetekhez vezet. Ezek közé sorolható a szociális értelemben vett visszahúzódás és érdektelenség, mely során a páciens vonakodik a társas helyzetektôl, elkerüli a régi barátokat és általában az embereket (Andersson és Deigham, 2006). A pozitív megküzdési stratégiák közé sorolják az aktív megküzdést, így azok az amputált betegek, akik aktív problémamegoldó megküzdést alkalmaznak, alacsonyabb mértékú depresszív tünetekrôl számolnak be (Livneh, Antonak és Gerhardt, 1999; Andersson és Deigham, 2006). Az aktív megküzdés része, hogy a páciens újra a társadalom produktív tagjává akar válni, ilyenkor gyakran munkahelyet vagy akár szakmát is vált. Ugyancsak adaptív stratégia a pozitív átkeretezés, például: „ha azt vesszük, akkor meg is halhattam volna, de élek...”; „sok embernek ennél is nagyobb problémája van, amit meg se tud oldani...” (Dunn, 1996). Pozitív megküzdési stratégia a tervezés is, ennek során a páciens kidolgoz saját magának célokat, részcélokat és az azokhoz vezetô utat, például: „minden reggel megcsinálom az elôírt gyakorlatokat, és betartom a diatetikus útmutatásait, így jobban fogok tudni járni..." (Oaksford, Frude és Cuddihy, 2005). Az elfogadás hasonlóan pozitív stratégia, melyben meghatározó tényezô a páciens életkora. Az alkalmazkodást megnehezíti, ha a beteg fiatalon veszíti el egy végtagját vagy annak egy részét (Andersson és Deigham, 2006). Emellett a humort mint megküzdési stratégiát számos szerzô kiemeli, hangsúlyozva, hogy a humor szerves része a megküzdési folyamatnak, pozitív eszköze az adaptációnak (Oaksford, Frude és Cuddihy, 2005).

A társas támogatás több formáját említik a kutatások, ezek közül többek között az érzelmi, valamint az instrumentális támogatást. Andersson és Deigham (2006) megerôsítik, hogy azok a betegek, akik a mútét elôtt rendelkeztek szociális, támogató kapcsolatokkal, kisebb valószínúséggel szenvedtek depresszív tünetektôl és fantomfájdalmaktól a mútétet követôen. A betegek segítségkérése ugyanakkor sokszor konkrét, a környezettel kapcsolatos problémára irányul, mint például a lakás átépítése, akadálymentesítése, azonban az ilyen típusú támogatás keresése a mûtétet követô elsô évben szignifikánsan csökken.

Vitathatatlan, hogy a csonkolás, a végtag elvesztése olyan trauma, amely a páciens korábbi életét teljesen felborítja. A végtag-amputáció mint stresszor próbára teszi a beteg képességeit a pszichés egyensúly tekintetében, azonban vannak, akik képesek jól alkalmazkodni a helyzethez, és a változás ellenére megôrzik mentális egészségüket. A kutatók a nehezített élethelyzethez történô sikeres alkalmazkodást a reziliencia jelenségével írják le. Masten és kutatócsoportja definíciója szerint (2001) a reziliencia a sikeres alkalmazkodás folyamatát, képességét vagy kimenetét is jelentheti a kihívást jelentô vagy fenyegetô körülmények ellenére. Reed-Victor és Stronge (2002) hasonló meghatározást ad, hozzátéve az eredeti definícióhoz az egyén erôforrásainak, gyengeségeinek, képességeinek és az egyén és környezete összeillésének (goodness-of-fit) szerepét a folyamatban. A reziliencia szerepével az alsóvégtag-amputált betegek esetében eddig kevéssé foglalkoztak (Dunn, Uswatte és Elliot, 2009; Walsh és mtsai, 2016), így a kutatások ezen a téren is egyre sürgetôbbek. Fredrickson és mtsai kutatásaik nyo- 
mán leírják, hogy a jobb rezilienciára való képességgel rendelkezó személy képes pozitív érzelmekrôl beszámolni stressz esetén is, ami hatékonyabb megküzdéshez vezet (Fredrickson, Tugade, Waugh és Larkin, 2003). Ezt az eredményt megerôsítik Walsh és mtsai (2016) azzal kiegészítve, hogy az alsóvégtag-amputált betegek körében, noha az amputáció utáni fizikai fájdalom, a depresszió és az aktivitás visszaesése csökkenti a pozitív érzelmek megjelenését, de a reziliens beteg nagyobb valószínúséggel mutat proaktív viselkedést, személyes jelentéssel teli életcélokat képes megfogalmazni, valamint nem izolálódik, hanem képes nyitni a külvilág felé.

A fenti megközelítések és eredmények figyelembevételével kutatási célkitûzésünkben a diabetes mellitus szövôdménye miatt alsóvégtag-amputált betegek lelki ellenálló képességére fókuszáltunk, különösképpen mentális egészségük megtartásának, alkalmazkodóképességük létrejöttének megértésére, valamint azon protektív és veszélyeztető tényezók feltárására, amelyek befolyással lehetnek az alkalmazkodási folyamat sikerességére.

\section{HIPOTÉZISEK}

H1: Az elsô vizsgálati idôpontban, az amputáció után egy hónappal (T1: mérési idôpont, amely az amputációt követô elsô hónapot jelöli) az alsóvégtag-amputáción átesettek pszichés állapotát leíró jellemzôk problémásabb képet mutatnak, mint az egészséges és a beteg kontrollcsoport, ami megnyilvánul (1.1.) a depresszív tünetek magasabb mértékében, a (1.2.) fokozott negatív érzelmi beállítódásban, a (1.3.) nagyobb fokú visszahúzódásban, a (1.4.) primitív, érzelmi jellegú megküzdési módok preferálásában és az (1.5.) alacsonyabb mértékú társas támogatás tapasztalatában. A beteg kontrollcsoporttal összevetve a depresszió mértéke várhatóan magasabb értéket mutat az amputált lábú cukorbetegek körében (1.6.).

H2: Az utánkövetés során (T2: mérési idôpont, ami az amputációt követô hatodik hónapot jelöli), az amputáció után fél évvel várhatóan csökkenést mutat a (2.1.) depresszió mértéke, amivel párhuzamosan (2.2.) növekszik az átélt pozitív érzelmek szintje, és (2.3.) egyben magasabb fokú reziliencia lesz jellemzô rájuk.

H3: A reziliencia mértékével mind a $\mathrm{T} 1$, illetve T2 időpontban pozitívan jár együtt (3.1.) a pozitív érzelmek és a (3.2.) társas támogatás szintje, míg a (3.3.) depresszió és a (3.4.) negatív érzelmek negatív kapcsolatban vannak a rezilienciával. A (3.5.) megküzdési módok esetén nem állapítható meg egyértelmú mintázat, negatív és pozitív együtt járások egyaránt azonosíthatók.

\section{MÓDSZER}

\section{Vizsgálati személyek}

Az alsóvégtag-amputált diabetes mellitusban szenvedô betegek $(\mathrm{n}=46)$ a Magyar Honvédség Egészségügyi Központ Rehabilitációs Intézetéből, valamint a Jahn Ferenc Dél-pesti Kórház Rehabilitációs Osztályáról kerültek ki. Kutatócsoportunk egyik tagja 
- aki a rehabilitációs osztályon dolgozik és a rehabilitációs team pszichológusa - segítségével történt az amputált betegek bevonása, illetve a kontrollcsoport toborzása. Az amputációs, illetve a rehabilitációs osztály fốorvosaival való szoros együttmúködés tette lehetôvé, hogy a betegeket vizsgáljuk, valamint az utánkövetésben nyomon követhessük. A pszichológus személyesen, egyenként kereste fel a betegeket az osztályon, továbbá hat hónappal késôbb, a betegek a végleges protézis céljából újra az osztályra kerültek, ahol megtörténhetett az utánkövetésük. Azokat a pácienseket, akik nem tértek vissza a rehabilitációs osztályra a protézis miatt, személyesen, a lakhelyükön kerestük fel, és kértük a kérdőívcsomag másodszori kitöltését. Az utánkövetés során történt kismértékú lemorzsolódás okai között az szerepelt, hogy a beteg elutasította a második találkozást, vagy idôközben elhunyt.

Az egészséges vizsgálati személyek $(\mathrm{n}=63)$ egy része kórházi dolgozókból áll, nagyobb részük függetlenül az intézménytôl tevôdött ki, figyelve arra, hogy az egészséges csoport életkorát a betegcsoport életkorához illesszük. Az egészséges mintába való bekerülés kritériuma volt, hogy a vizsgált személyt nem kezelik sehol mentális betegséggel, nem diagnosztizált cukorbeteg, valamint nem esett át csonkolásos mútéten. Emellett a vizsgálatba beteg kontrollcsoportként diabetes mellitusban szenvedó betegeket vontunk be $(n=54)$, akik a Honvédkórház Rehabilitációs Osztályáról kerültek ki. A beteg kontrollcsoportba való bekerülés kritériuma az volt, hogy a beteg diagnosztizált 2-es típusú cukorbeteg legyen, gondozás alatt álljon, vagyis havi rendszerességgel jelenjen meg kontrollon a kórház ambulanciáján, minimum egy szövôdménnyel rendelkezzen a cukorbetegségbôl fakadóan, inzulin-, illetve gyógyszeres terápiában részesüljön, valamint amputációs mútétje nem volt. Az alsóvégtag-amputált betegeket utánkövetéssel vizsgáltuk az amputációt követô elsô és hatodik hónapban. Az 1. táblázatban foglaltuk össze az amputált betegek, valamint a kontrollcsoportok demográfiai hátterét. Az alsóvégtag-amputált vizsgálati mintánktól két idôpontban gyújtöttünk adatokat, a két mérési idôpontot T1 és T2-nek neveztük el. A T1 az amputációt követô elsố hónapban történt mérési idôpontot jelzi, a T2-es mérési idôpont az amputációt követô hatodik hónapra vonatkozik. Az amputáció indikációja szerint mindegyik vizsgálati személynél nem traumás (diabetes mellitus szövôdménye) ok áll az amputáció hátterében. A mintába való bekerülés további kritériuma az írás és olvasás készség volt, mivel a betegek önállóan töltötték ki a kézhez kapott kérdőíveket. A vizsgálatban való részvétel önkéntes volt, melyre a betegtájékoztató és a beleegyezô nyilatkozat elfogadása után került sor. A kérdôív kitöltése anonim módon történt, a betegeket jelige megadásával lehetett azonosítani a második alkalommal történố kitöltéskor. A vizsgálati személyek ellenjuttatást nem kaptak a vizsgálatban történô részvételért. A 2. táblázatban a vizsgálati csoportok leíró statisztikai adatait foglaltuk össze. A magyarországi szabályozásnak megfelelôen az Egészségügyi Tudományos Tanács Tudományos és Kutatásetikai Bizottsága kutatásunkhoz megadta a szakmai etikai engedélyt (engedély száma: 35135-2/2017/EKU). A vizsgálati személyeket érintô további adatokért lásd az 1. táblázatot. 
1. táblázat. A vizsgálati minta demográfiai jellemzői

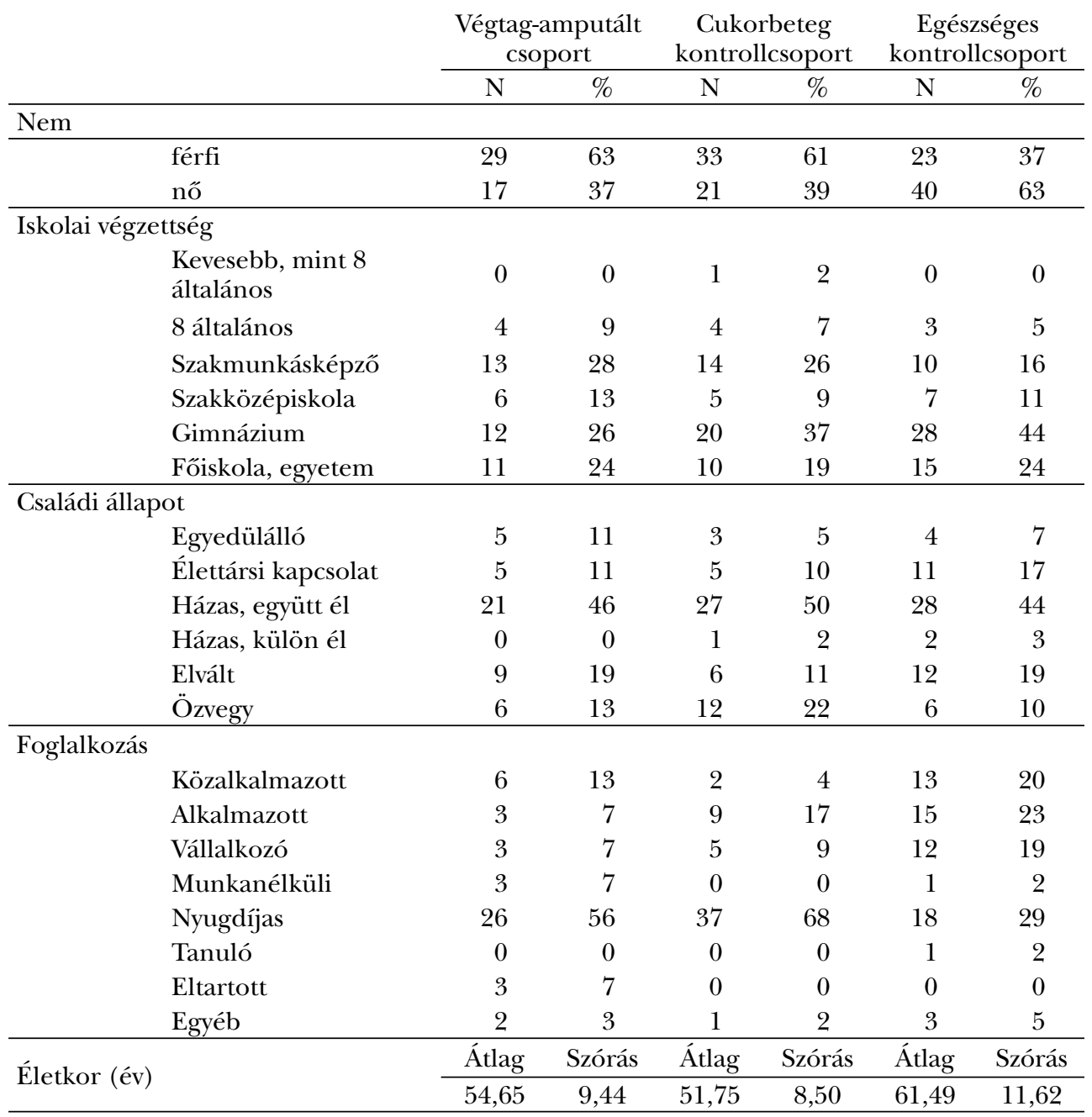

\section{Méröeszközök}

Az amputáción átesett vizsgálati személyek egy általunk összeállított kérdőívcsomagot töltöttek ki, amely a szociodemográfiai kérdéseken túl a következô kérdôíveket tartalmazta:

A depresszió tünetegyüttest a Beck Depresszió Kérdôív (BDI-R, Beck, Ward, Mendelson, Mock és Erbaugh, 1961) magyarra adaptált, 9 tételes, négyfokú Likertskálával rendelkezô rövidített változatával mértük (magyar adaptáció: Rózsa, Szádóczky, Füredi, 2001). A kérdôív a depresszió olyan tüneteire kérdez rá, mint a szociális 
visszahúzódás, döntésképtelenség, alvászavar, fáradékonyság, túlzott aggódás a testi tünetek miatt, munkaképtelenség, pesszimizmus, az elégedettség és az öröm hiánya, valamint az önvád. A kérdôív olyan tételeket tartalmaz, mint például: „Minden érdeklődésemet elvesztettem mások iránt”, ahol egy négyfokú Likert-skálán kell eldöntenie a vizsgálati személynek, hogy egyáltalán nem jellemzô vagy teljesen jellemzô rá az állítás. Vizsgálatunkban a belsố konzisztenciát kifejezó Cronbach-alfa értéke: 0,947.

A második kérdôív a Pozitív és Negatív Affektivitás Skála volt (PANAS) (Positive and Negative Affectivity Schedule - PANAS; Watson, Clark és Tellegen, 1988; magyar adaptáció Gyollai, Simor, Köteles és Demetrovics, 2011). A PANAS 20 tételes kérdôív, amelyet a pozitív és negatív érzelmi állapotok mérésére dolgoztak ki. Az eredeti mérốeszköz 10-10 pozitív (pl. lelkes, figyelmes), illetve negatív (pl. zaklatott, ingerlékeny) érzelmi állapotot leíró tételt tartalmaz, melyeket ötfokú Likert-skálán kell értékelni. A kérdôív olyan tételeket tartalmaz, mint például: „Elhivatott vagy aktív, élénk”, ami a pozitív érzelmi állapotra kérdez rá vagy éppen ellentétesen, a negatív érzelmi állapotát méri a személynek, például: „kiborult, magamon kívül vagyok”. Vizsgálatunkban a belsố konzisztenciát kifejezô Cronbach-alfa értékek 0,907 (pozitív) és 0,937 (negatív) voltak.

A harmadik kérdőív a MOS-SSS (Medical Outcomes Study Social Support Survey), (továbbiakban MOS-SSS), a társas támogatás mértékének mérését szolgáló önkitöltôs kérdôív volt, megalkotói Sherbourne és Stewart (1991), melynek magyar adaptációját (Makó és mtsai, 2016) használtuk fel. A MOS-SSS 20 tételt tartalmaz, melybốl az elsô a bizalmi kapcsolatok számát, azaz a társas támaszt nyújtó szociális háló kiterjedtségét azonosítja: 1. tétel: „Körülbelül hány olyan közeli barátja és rokona van, akikkel nem feszélyezi magát, és bármirôl tud beszélgetni, ami az eszébe jut." Míg a 2. tételtôl a 20.-ig 19 item a társas támasz különbözô megjelenési formáin keresztül méri az egyén támogatottságát, például: „Akad valaki, akivel bizalmasan beszélhet önmagáról és a problémáiról.” A kérdőív kitöltőinek egy ötfokú Likert-skálán kell eldöntenie, hogy az adott támaszfajta milyen gyakran áll a személy rendelkezésére. A szerzôk a társas támasz globális mutatója mellett 3 további alfaktort különítettek el, melyek az érzelmi és információs támasz, az instrumentális vagy kézzelfogható támasz és a pozitív szociális interakción alapuló támasz. Vizsgálatunkban a belsố konzisztenciát kifejezô Cronbach-alfa értékek 0,897 és 0,970 között helyezkedtek el.

A negyedik a Folkman és Lazarus-féle Konfliktusmegoldó Kérdôív, amely a megküzdési stratégiák elkülönítésére szolgáló kérdôíves eljárás (Ways of Coping Inventory, WOC; Folkman és Lazarus, 1980). Vizsgálatunk a kérdôív Kopp által elkészített (Kopp, 1994) magyar adaptációjával történt. A 22 tételes kérdőív a nehéz élethelyzetekben mutatott viselkedést tárja fel. A vizsgált személyeknek az állítások alapján egy négyfokú skálán kell jellemezniük viselkedésüket az egyáltalán nem jellemzô és a teljesen jellemzó közötti intervallumban. A kérdôív olyan tételeket tartalmaz, mint például: „Átgondoltam, hogy mit fogok mondani vagy tenni az ügyben.” A kérdôív a problémaorientált, feladatközpontú megküzdéshez sorolja a céltudatos cselekvést, a problémaelemzést és az alkalmazkodást. Az érzelmi típusú megküzdéshez tartozik az érzelmi típusú cselekvés, az érzelmi egyensúlykeresés, valamint a visszahúzódás. Továbbá a támogatást keresố konfliktuskezelési stratégiához sorolható a segítségkérés, ám ezt a komponenst az alacsony szintú megbízhatósága miatt nem vontuk be az elem- 
zésbe (Rózsa, Purebl és Susánszky, 2008). Vizsgálatunkban a belsố konzisztenciát kifejezô Cronbach-alfa értékek 0,631 és 0,742 között helyezkedtek el.

Az ötödik kérdôív a Connor-Davidson Reziliencia Skála (Connor-Davidson Resilience Scale - CD-RISC; Connor és Davidson, 2003) volt, amely a nehézségekkel való sikeres megküzdés mérésére kidolgozott kérdőív, s melynek a 10 itembôl álló változatát (Campbell-Sills és Stein, 2007) használtuk fel (a magyar adaptációval kapcsolatos adatokat ld. Járai és mtsai, 2015). A résztvevôk ötfokú Likert-skálán - $0=$ egyáltalán nem igaz; 4 = szinte mindig igaz - értékelik az egyes tételeket. A kérdôív olyan tartalmú tételeket tartalmaz, mint például: „Képes vagyok arra, hogy alkalmazkodjak a változásokhoz” vagy „Tisztán gondolkodom és koncentrálok, amikor nyomás alatt vagyok”. A kérdőívben elért pontszámok a 0-40 közötti tartományba sorolhatók, a magasabb pontérték magasabb rezilienciára utal. Vizsgálatunkban a belsố konzisztenciát kifejezó Cronbach-alfa értéke: 0,956.

\section{Statisztikai módszerek}

A statisztikai vizsgálatokat multiplatformos megoldásban kiviteleztük, az IBM SPSS 25, a jamovi és a JASP programok segítségével. Az eloszlásvizsgálatok eredményeit és számos vizsgálati forrást figyelembe véve a csoportközi különbségek összehasonlítása Kruskal-Wallis-próba segítségével történt, az idôbeli hatások a Wilcoxon-próba használatával, míg az együtt járások vizsgálatát a Spearman-féle korrelációs eljárások tették lehetôvé. A hatásnagyság kifejezésére az éta-négyzet indikátort választottuk, ahol a 0,02-0,13 övezetben alacsony, a 0,13-0,26 övezetben közepes, míg ez érték felett magas hatásnagyságról számolhatunk be.

\section{EREDMÉNYEK}

\section{Az elsô hipotézis vizsgálatának eredményei}

Annak eldöntésére, hogy az alsóvégtag-amputáción átesett betegek pszichés jellemzôi problémásabb képet mutatnak-e, mint az egészséges és a beteg kontrollcsoport, Kruskal-Wallis-próbát alkalmaztunk. Azért erre a nem parametrikus próbára esett a választásunk, mert a vizsgált változók egyike esetén sem teljesült a normális eloszlás feltétele.

A depresszió mértéke az alsóvégtag-amputált betegek esetén magasabbnak bizonyult, mint a beteg vagy egészséges kontrollcsoportnál, míg a két kontrollcsoport nem különbözött egymástól. Ezek alapján az (1.1.) és az (1.6.) hipotézis helytállónak bizonyult.

A depresszió mértékéhez hasonlóan az (1.2.) hipotézisben megfogalmazottak szerint magasabb volt az átélt negatív érzelmek mértéke is az amputáción átesett csoportban, mint a két kontrollcsoport esetén, melyek ezúttal sem különböztek egymástól. Ezáltal ez a hipotézisünk is helytállónak bizonyult.

A reziliencia mértéke szignifikánsan kisebb az amputált lábú cukorbetegeket és a két kontrollcsoportot összevetve. 
A visszahúzódás mint megküzdési mód tekintetében (1.3.) ugyanakkor nem tapasztalható különbség a vizsgált csoportok között, ahogy az sem bizonyult helytállónak, hogy (1.4.) az amputáción átesett cukorbetegek inkább preferálják az érzelmi jellegú megküzdési módokat: az érzelmi indíttatású cselekvések esetén nem volt megfigyelhetố különbség, míg az érzelmi egyensúly keresésének tekintetében az egészséges kontrollcsoport dominanciája mutatkozott meg. Ezek alapján nem nyert igazolást sem az (1.3.), sem az (1.4.) hipotézis. A további összehasonlításban azt kaptuk, hogy a megküzdési módok tekintetében az alsóvégtag-amputált cukorbeteg az amputációt követô elsô hónapban kevésbé alkalmazza az egészséges kontrollcsoporthoz képest a problémaelemzést, a céltudatos cselekvést, az érzelmi egyensúly keresését mint copingstratégiát.

Az átélt társas támogatás mértékét illetốen (1.5.) helytállónak bizonyult az a feltételezés, hogy ezek a jellegzetességek alacsonyabb mértéket mutatnak az alsóvégtag-amputáltak csoportjában az egészséges kontrollal összevetve. Igaz ez az érzelmi információs támasz, a pozitív szociális interakción alapuló támasz és az összesített mutató esetén, míg az instrumentális támasz tekintetében nem volt kimutatható különbség. A fentiek alapján az (1.5.) hipotézis részben beigazolódott. További információkért ld. a 2. és 3. táblázatot.

2. táblázat. A vizsgálati csoportok leíró statisztikai adatai

\begin{tabular}{|c|c|c|c|c|c|c|c|c|c|}
\hline \multirow[b]{2}{*}{ Csoport } & \multicolumn{3}{|c|}{ Átlag } & \multicolumn{3}{|c|}{ Medián } & \multicolumn{3}{|c|}{ Szórás } \\
\hline & $\mathrm{T} 1$ & $\mathrm{C}$ & $\mathrm{E}$ & $\mathrm{T} 1$ & $\mathrm{C}$ & $\mathrm{E}$ & $\mathrm{T} 1$ & $\mathrm{C}$ & $\mathrm{E}$ \\
\hline Depresszió (BDI-R) & 20,2 & 14,1 & 13,3 & 19,5 & 13 & 12 & 7,9 & 4,3 & 4,1 \\
\hline Pozitív érzelmek (PANAS) & 28,1 & 31,9 & 35,3 & 26 & 32,5 & 38 & 8,3 & 7,8 & 8,7 \\
\hline Negatív érzelmek (PANAS) & 23,7 & 17,0 & 15,1 & 19,5 & 15 & 13 & 11,1 & 7,0 & 5,7 \\
\hline Reziliencia (CD-RISC) & 21,6 & 28,7 & 29,0 & 24 & 30 & 32 & 11,2 & 6,9 & 7,8 \\
\hline $\begin{array}{l}\text { Érzelmi információs } \\
\text { támasz (MOS) }\end{array}$ & 29,6 & 31,7 & 34,1 & 29 & 34 & 37 & 8,8 & 8,1 & 7,8 \\
\hline $\begin{array}{l}\text { Pozitív szociális interakción } \\
\text { alapuló támasz (MOS) }\end{array}$ & 25,9 & 28,1 & 30,6 & 26 & 31 & 33 & 8,3 & 7,9 & 6,2 \\
\hline $\begin{array}{l}\text { Instrumentális támasz } \\
\text { (MOS) }\end{array}$ & 16,0 & 16,9 & 17,4 & 17 & 19 & 19 & 4,1 & 4,3 & 3,9 \\
\hline $\begin{array}{l}\text { Összesített társas támogatás } \\
\text { (MOS) }\end{array}$ & 72,6 & 79,5 & 84,8 & 72 & 88 & 91 & 22,3 & 20,4 & 17,6 \\
\hline Problémaelemzés (WOC) & 4,9 & 5,4 & 6,4 & 6 & 6 & 6 & 2,4 & 1,8 & 1,5 \\
\hline $\begin{array}{l}\text { Céltudatos cselekvés } \\
\text { (WOC) }\end{array}$ & 5,3 & 6,8 & 6,9 & 6 & 7 & 7 & 2,9 & 3,0 & 2,6 \\
\hline $\begin{array}{l}\text { Érzelmi indíttatású } \\
\text { cselekvés (WOC) }\end{array}$ & 4,0 & 3,1 & 2,7 & 3 & 3 & 2 & 3,2 & 2,2 & 2,0 \\
\hline Alkalmazkodás (WOC) & 5,2 & 5,8 & 5,8 & 6 & 6 & 6 & 2,2 & 2,1 & 2,2 \\
\hline $\begin{array}{l}\text { Érzelmi egyensúly keresése } \\
\text { (WOC) }\end{array}$ & 2,0 & 3,2 & 3,2 & 3 & 3 & 3 & 1,3 & 1,6 & 1,6 \\
\hline Visszahúzódás (WOC) & 4,8 & 4,2 & 4,3 & 4 & 4 & 4 & 2,3 & 2,4 & 2,0 \\
\hline
\end{tabular}

Megjegyzés: T1 - alsóvégtag-amputált betegek az elsố adatfelvételi idôpontban; C - cukorbeteg kontrollcsoport; E - egészséges kontrollcsoport 
3. táblázat. A vizsgálati csoportok közötti különbségek vizsgálatának eredményei

\begin{tabular}{lccccc} 
& $\chi^{2}$ & $\mathrm{df}$ & $\mathrm{p}$ & $\varepsilon^{2}$ & $\mathrm{DSCF}-\mathrm{PC}$ \\
\hline Depresszió (BDI-R) & $23,14^{* * *}$ & 2 & $<0,001$ & 0,14 & $\mathrm{~T} 1>\mathrm{C} \& \mathrm{E}$ \\
Pozitív érzelmek (PANAS) & $19,82^{* * * *}$ & 2 & $<0,001$ & 0,12 & $\mathrm{E}>\mathrm{C}>\mathrm{T} 1$ \\
Negatív érzelmek (PANAS) & $19,62^{* * * *}$ & 2 & $<0,001$ & 0.12 & $\mathrm{~T} 1>\mathrm{C} \& \mathrm{E}$ \\
Reziliencia (CD-RISC) & $13,69^{* *}$ & 2 & 00,001 & 0,08 & $\mathrm{C} \& \mathrm{E}>\mathrm{T} 1$ \\
Érzelmi információs támasz (MOS) & $8,10^{*}$ & 2 & 00,017 & 0,05 & $\mathrm{E}>\mathrm{T} 1$ \\
Pozitív szociális interakción alapuló & $7,01^{*}$ & 2 & 00,030 & 0,04 & $\mathrm{E}>\mathrm{T} 1$ \\
támasz (MOS) & 2,81 & 2 & 00,245 & 0,01 & - \\
Instrumentális támasz (MOS) & $7,87^{*}$ & 2 & 00,019 & 0,05 & $\mathrm{E}>\mathrm{T} 1$ \\
Összesített társas támogatás (MOS) & $12,51^{* *}$ & 2 & 00,002 & 0,07 & $\mathrm{E}>\mathrm{T} 1 \& \mathrm{C}$ \\
Problémaelemzés (WOC) & $9,14^{*}$ & 2 & 00,010 & 0,05 & $\mathrm{C} \& \mathrm{E}>\mathrm{T} 1$ \\
Céltudatos cselekvés (WOC) & 2,94 & 2 & 00,229 & 0,01 & - \\
Érzelmi indíttatású cselekvés (WOC) & 2,30 & 2 & 00,315 & 0,01 & - \\
Alkalmazkodás (WOC) & $7,44^{*}$ & 2 & 00,024 & 0,04 & $\mathrm{E}>\mathrm{T} 1$ \\
Érzelmi egyensúly keresése (WOC) & 1,67 & 2 & 00,432 & 0,01 & - \\
Visszahúzódás (WOC) & & & & & \\
\hline
\end{tabular}

Megjegyzés: DSCF-PC: Dwass, Steel, Critchlow-Fligner páros összehasonlítás; T1 - alsóvégtag-amputált betegek az elsố adatfelvételi idôpontban; C - cukorbeteg kontrollcsoport; E - egészséges kontrollcsoport; " $\mathrm{p}<0,05 ;{ }^{* *} \mathrm{p}<0,01 ;{ }^{* * *} \mathrm{p}<0,001$

\section{A második hipotézis vizsgálatának eredményei}

A két adatfelvételi idôpont között eltelt idóben bekövetkezô feltételezett pszichológiai változások tesztelésére Wilcoxon-próbát alkalmaztunk. A depresszió (2.1.) mértéke az elvártaknak megfelelôen szignifikáns csökkenést mutatott, ami által az elsô alhipotézis helytállónak bizonyult. A pozitív érzelmek (2.2.) és a reziliencia (2.3.) mértékének növekedésére vonatkozó feltételezés szintén beigazolódott, azaz az idő elôrehaladtával mind a pozitív affektusok átélésének mértéke, mind pedig a reziliencia szintje magasabbnak bizonyult. A negatív érzelmek dominanciája pedig csökken az alsóvégtag-amputált betegek esetében a hatodik hónap után. A társas támogatás mértéke ezzel együtt nô, a pozitív szociális interakción alapuló támasz dominanciája mutatkozik meg a vizsgálati csoport tekintetében. A megküzdési módok tekintetében a céltudatos cselekvés és a problémaelemzés lesz domináns az amputált betegek körében, ezen megküzdési stratégiák szignifikáns különbséget mutatnak fél évvel késôbb. További részletes eredményekért ld. a 4 . táblázatot.

\section{A harmadik hipotézis vizsgálatának eredményei}

A két vizsgálati idôpontban annak ellenôrzésére, hogy a vizsgált változók milyen módon járnak együtt a reziliencia mértékével, Spearman-féle rangkorrelációt alkalmaztunk. A pozitív érzelmek esetén (3.1.) mindkét idôpontban beigazolódott a feltéte- 
4. táblázat. Az alsóvégtag-amputált csoport összehasonlítása T1 és T2 időpontokban

\begin{tabular}{|c|c|c|c|c|c|c|c|c|c|}
\hline & \multicolumn{2}{|c|}{ Átlag } & \multicolumn{2}{|c|}{ Medián } & \multicolumn{2}{|c|}{ Szórás } & \multirow[t]{2}{*}{$\mathrm{W}$} & \multirow[t]{2}{*}{$\mathrm{p}$} & \multirow[t]{2}{*}{$\varepsilon^{2}$} \\
\hline & $\mathrm{T} 1$ & $\mathrm{~T} 2$ & $\mathrm{~T} 1$ & $\mathrm{~T} 2$ & $\mathrm{~T} 1$ & $\mathrm{~T} 2$ & & & \\
\hline Depresszió (BDI-R) & 20,2 & 15,6 & 19,5 & 15 & 7,9 & 4,6 & 705 & $0,001^{* * *}$ & 0,06 \\
\hline $\begin{array}{l}\text { Pozitív érzelmek } \\
\text { (PANAS) }\end{array}$ & 28,1 & 32,9 & 26 & 34 & 8,3 & 7,0 & 208 & $0,001^{* *}$ & 0,19 \\
\hline $\begin{array}{l}\text { Negatív érzelmek } \\
\text { (PANAS) }\end{array}$ & 23,7 & 19,6 & 19,5 & 20 & 11,1 & 7,4 & 712 & $0,012^{*}$ & 0,06 \\
\hline Reziliencia (CD-RISC) & 21,6 & 28,5 & 24 & 28 & 11,2 & 7,0 & 175 & $0,001^{* *}$ & 0,21 \\
\hline $\begin{array}{l}\text { Érzelmi információs } \\
\text { támasz (MOS) }\end{array}$ & 29,6 & 30,5 & 29 & 32 & 8,8 & 7,7 & 283 & 0,136 & 0,17 \\
\hline $\begin{array}{l}\text { Pozitív szociális inter- } \\
\text { akción alapuló támasz } \\
\text { (MOS) }\end{array}$ & 25,9 & 26,8 & 26 & 28,5 & 8,3 & 7,2 & 173 & $0,020^{*}$ & 0,21 \\
\hline $\begin{array}{l}\text { Instrumentális támasz } \\
\text { (MOS) }\end{array}$ & 16,0 & 16,6 & 17 & 18 & 4,1 & 3,5 & 124 & 0,071 & 0,22 \\
\hline $\begin{array}{l}\text { Összesített társas } \\
\text { támogatás (MOS) }\end{array}$ & 72,6 & 75,6 & 72 & 77,5 & 22,3 & 19,3 & 224 & $0,013^{*}$ & 0,19 \\
\hline $\begin{array}{l}\text { Problémaelemzés } \\
\text { (WOC) }\end{array}$ & 4,9 & 5,7 & 6 & 6 & 2,4 & 2,0 & 157 & $0,044^{*}$ & 0,21 \\
\hline $\begin{array}{l}\text { Céltudatos cselekvés } \\
\text { (WOC) }\end{array}$ & 5,3 & 6,6 & 6 & 7 & 2,9 & 2,4 & 165 & $0,008^{* *}$ & 0,21 \\
\hline $\begin{array}{l}\text { Érzelmi indíttatású } \\
\text { cselekvés (WOC) }\end{array}$ & 4,0 & 3,3 & 3 & 3 & 3,2 & 2,7 & 380 & 0,075 & 0,14 \\
\hline Alkalmazkodás (WOC) & 5,2 & 5,6 & 6 & 6 & 2,2 & 1,8 & 290 & 0,241 & 0,17 \\
\hline $\begin{array}{l}\text { Érzelmi egyensúly } \\
\text { keresése (WOC) }\end{array}$ & 2,0 & 2,7 & 3 & 3 & 1,3 & 1,6 & 157 & 0,288 & 0,21 \\
\hline Visszahúzódás (WOC) & 4,8 & 4,8 & 4 & 5 & 2,3 & 1,8 & 326 & 0,917 & 0,16 \\
\hline
\end{tabular}

Megjegyzés: ${ }^{\mathrm{p}}<0,05 ;{ }^{* * *} \mathrm{p}<0,01$

lezett pozitív együttjárás. A társas támogatás mértékét kifejezô gyưjtôváltozó esetén szintén mindkét adatfelvételi idôpontban közepes erôsségú pozitív korreláció volt, ami megerôsíti a (3.2.) hipotézist. A depresszió (3.3.) és a negatív érzelmek (3.4.) az elvártaknak megfelelốen negatívan jártak együtt mindkét adatfelvételi idôpontban a reziliencia mértékével, ahol is a depresszió erôteljesebb kapcsolatban állt a rezilienciával, mint a negatív érzelmek. A preferált megküzdési módok esetén helytállónak bizonyult a feltételezés, hogy vegyes mintázat figyelhetô meg. A céltudatos cselekvések mindkét idôpontban pozitívan jártak együtt a reziliencia mértékével, míg az érzelmi indíttatású cselekvések mindkét esetben negatívan. A problémaelemzés, az érzelmi egyensúly keresése és a visszahúzódás csupán az elsố idôpontban állt igazolhatóan kapcsolatban a rezilienciával, míg az alkalmazkodás csupán a második esetben. Ezek alapján a 3.5. hipotézis is igazoltnak tekinthetô. További részletes adatokért lásd az 5. táblázatot. 
5. táblázat. Az alsóvégtag-amputált csoport rezilienciával való korrelációs értékei T1 és T2 idôpontokban

\begin{tabular}{lrrrc} 
& \multicolumn{3}{c}{$\mathrm{T} 1$} & \multicolumn{1}{c}{$\mathrm{T} 2$} \\
\cline { 2 - 5 } & \multicolumn{1}{c}{$\mathrm{r}_{\mathrm{s}}$} & \multicolumn{1}{c}{$\mathrm{p}$} & \multicolumn{1}{c}{$\mathrm{r}_{\mathrm{s}}$} & \multicolumn{1}{c}{$\mathrm{p}$} \\
\hline Depresszió (BDI-R) & $-0,608$ & $<0,001^{* * * *}$ & $-0,778$ & $<0,001^{* * * *}$ \\
Pozitív érzelmek (PANAS) & 0,712 & $<0,001^{* * *}$ & 0,336 & $<0,05^{*}$ \\
Negatív érzelmek (PANAS) & $-0,577$ & $<0,001^{* * * *}$ & $-0,551$ & $<0,001^{* * * *}$ \\
Érzelmi információs támasz (MOS) & 0,488 & $<0,001^{* * *}$ & 0,474 & $<0,001^{* * *}$ \\
Pozitív szociális interakción alapuló & 0,445 & $<0,001^{* * *}$ & 0,535 & $<0,001^{* * * *}$ \\
támasz (MOS) & 0,460 & $<0,001^{* * *}$ & 0,586 & $<0,001^{* * *}$ \\
Instrumentális támasz (MOS) & 0,472 & $<0,001^{* * *}$ & 0,506 & $<0,001^{* * *}$ \\
Összesített társas támogatás (MOS) & 0,394 & $<0,001^{* * *}$ & $-0,040$ & 0,375 \\
Problémaelemzés (WOC) & 0,470 & $<0,001^{* * *}$ & 0,302 & $<0,05^{*}$ \\
Céltudatos cselekvés (WOC) & $-0,371$ & $<0,001^{* * *}$ & $-0,474$ & $<0,001^{* * *}$ \\
Érzelmi indíttatású cselekvés (WOC) & 0,038 & 0,314 & 0,296 & $<0,05^{*}$ \\
Alkalmazkodás (WOC) & 0,226 & $<0,01^{* *}$ & $-0,081$ & 0,234 \\
Érzelmi egyensúly keresése (WOC) & $-0,215$ & $<0,01^{* *}$ & $-0,133$ & 0,543 \\
Visszahúzódás (WOC) & & & & \\
\hline
\end{tabular}

Megjegyzés: ${ }^{*} \mathrm{p}<0,05 ;{ }^{* *} \mathrm{p}<0,01 ;{ }^{* * * *} \mathrm{p}<0,001$

\section{MEGBESZÉLÉS}

Az eredmények azt mutatják, hogy az amputált lábú cukorbetegek egyik legjelentôsebb pszichés jellemzője a depresszió élménye. Azt feltételeztük, hogy a csonkolást követô elsố hónapban az amputált betegeknél a depresszió tünetei megjelennek, sốt szignifikánsan magasabb értéket fognak mutatni, mint a két kontrollcsoportnál. Az amputált betegek esetében a depresszió mértékében megjelenô különbség már az elsô mérési idôpontban, a csonkolást követố elsố hónapban megjelenik, azonban annak mértéke késôbb változik. Ahogy telik az idô, hat hónappal a mútét után a depresszív tünetképzôdés csökken. Az utánkövetéses vizsgálatunkból kiderül, hogy a depresszió mértéke csökken a hatodik hónap után, de a depresszió továbbra is követendô tényezô. A depresszió és a reziliencia összefüggését vizsgálva az eredményeink azt igazolják, hogy a depresszió veszélyeztetố tényezôként van jelen a betegcsoportban, ami a sikeres alkalmazkodást hátráltatja. A jobb rezilienciával rendelkezô beteg kevésbé depressziós, de a depresszív tünetképzôdés negatív irányban határozza meg az új élethelyzettel való megküzdést. Az eredményeink ezáltal alátámasztják azon kutatások eredményeit, amelyek hangsúlyozzák, hogy vannak olyan pszichés válaszreakciók, amelyek szinte minden cukorbetegnél jelentkeznek. Ezek közül jellemzô reakció a depresszió érzése, a szociális helyzetekben fellépó nehézségek, a csökkent életminôség és a gyászreakció (Eisner és mtsai, 2001; Desmond és MacLachlan, 2002). A kezdeti sokk után a depreszszió intenzitása csökken, ami támogatja a reziliencia létrejöttét. A depresszív tünetegyüttes az egyik legjellemzóbb pszichés reakció a csonkolást követôen, és a depresszív állapot akár 10 év múlva is fennállhat (Rajiv és mtsai, 2007). A szerzôk leírják, hogy a 
szorongás és a depresszív tünetek mérséklôdése nagymértékben a rehabilitációs osztály támogató szerepének köszönhetô, amely pszichésen biztonságot és védelmet nyújt a betegeknek, emellett a valósággal való szembenézést, a megküzdést is pozitívan befolyásolja.

A depresszió mellett a negatív érzelmek jelenlétét vizsgálatunkban megerôsíti, hogy a PANAS alapján az amputált lábú vizsgálati csoport az egészségesekkel és a cukorbetegekkel összevetve inkább negatív érzelmekkel jellemezhetô, a pozitív érzelmek megélése elmarad a kontrollcsoportokhoz képest.

A depresszió mellett a másik legerôteljesebb kapcsolatot az amputációt követô elsô hónap után a PANAS pozitív érzelmek alskálája mutatja. A kérdốiv ezen alskálája az olyan pozitív érzelmi-hangulati beállítódást méri, mint pl. lelkesedés, aktivitás, éberség. Vizsgálati kiindulópontunkban azt feltételeztük, hogy a pozitív érzések túlsúlya, vagyis a pozitív beállítottság szorosan együtt jár a rezilienciával, amit a kapott eredményeink meg is erôsítenek. Alátámasztást nyert továbbá azon feltételezésünk, hogy az amputációt követô hatodik hónap után a betegek több pozitív érzelmet mutatnak. Az eredmény egybecseng azon vizsgálatok eredményével, amelyek szerint az olyan pozitív érzelmek, mint a nyitottság, energikusság, remény, optimizmus általában szoros összefüggést mutatnak a magasabb rezilienciaértékekkel (Block és Block, 1980; Werner és Smith, 1992; Wolin és Wolin 1993; Klohnen, 1996; Masten, 2001). Emellett fordított összefüggést vártunk és kaptunk a negatív érzelmi állapotok (pl. zaklatott, ingerlékeny) és a reziliencia kapcsolatára vonatkozóan, amelyet a PANAS negatív alskálája mutat meg. A kapott eredmények megerôsítették, hogy azoknál az amputált lábú betegeknél, akiknél túlsúlyban voltak a negatív érzelmek, a reziliencia szignifikánsan alacsonyabb értéket mutatott. Az amputáció után pár héttel mindkét kontrollcsoporthoz képest több negatív érzelmet mutat egy csonkoláson átesett cukorbeteg. A negatív érzelmi beállítódás mértéke fél év után csökken, az elvárásunknak megfelelôen kedvezôtlenebb lesz a reziliencia szempontjából a negatív érzelmek megélése, ugyanakkor az összefüggések azt is megerôsítik, hogy miközben a negatív érzelmek jelenléte veszélyezteti az amputált beteg megváltozott állapotához történô alkalmazkodását, a jelen lévô pozitív érzelmek továbbra is támogatják az alkalmazkodás és a rehabilitáció sikerességét. A pozitív érzelmek tehát pozitív kapcsolatot mutatnak a rezilienciával, ezzel ellentétesen a depresszió és a negatív affektus gyengítik az amputált lábú cukorbeteg reziliens reakcióját.

A hipotézisünk alapján továbbá azt vártuk, hogy a csonkolást követôen az elsô hónapban a betegek a kontrollcsoporttal összevetve az élethelyzetbôl adódóan jobb társas támogatással rendelkeznek, ez a várakozásunk nem igazolódott be. Az amputált betegcsoport a társas támasz tekintetében szignifikánsan kisebb támogatottságot mutat, így az egészséges személyek társas támogatottságához viszonyítva alacsonyabb a pozitív szociális interakción alapuló támasz, valamint az érzelmi információs támasz is. Azonban a társas támogatás jelentôsége nố az idô elôrehaladtával, a hatodik hónap után szignifikánsan magasabb az amputált betegek társas támogatottsága. Noha a társas támogatottság feltételezhetôen nem változik vagy csak kismértékben, azonban annak megélése módosulhat. A társas támogatás pozitív irányú változásának megélését magyarázhatja a depresszió mértékének és a negatív érzelmek dominanciájának csökkenése. Ezt erôsíti az is, miszerint a társas támasz (MOS-SSS) összértéke mind- 
két mérési idôpontban pozitív kapcsolatot mutatott a rezilienciával, amely a hatodik hónap után erôsebbé válik. A kérdốiv mindhárom alskálája hasonlóképpen mindkét mérési idôpontban szignifikáns kapcsolatokat mutat a rezilienciával, az érzelmiinformációs támasz, szociális interakción alapuló támasz, valamint az instrumentációs támasz esetében is.

A kapott eredmények alapján látható, hogy a magasabb társas támogatottság magasabb pozitív affektivitással, alacsonyabb negatív affektivitással, valamint alacsonyabb depresszióval társul. A társas támasszal kapcsolatos eredményeink összhangban állnak azon kutatásokkal, melyek a társas támogatottság és a mentális egészség közötti összefüggéseket hangsúlyozzák (Cobb, 1976; Séguin, Potvini, Denis és Loiselle, 1995; Uchino, Cacioppo és Kiecolt-Glaser, 1996; Coker és mtsai, 2002). A kapott eredmények egybecsengenek a Rajiv és mtsai (2007) által leírtakkal, hogy a végtag-amputáción keresztül ment egyedül élô betegek kisebb mértékú társas támogatással rendelkeznek, ami magasabb depresszió- és szorongásértékekkel jár együtt, valamint ezen betegek szignifikánsan hosszabb idốt töltenek az amputációs-rehabilitációs osztályokon. Más szerzôk arra is rámutatnak, hogy a szociális kapcsolatokba történô beágyazódottság hiánya az egészség-magatartáson keresztül is visszahat az egyén egészségi állapotára (ld. alkoholfogyasztás, dohányzás, szürésre járás problematikája) (Berkman, 1995). Mindebbôl következôen kiemelt szerepe van annak, hogy a kórházi ellátáson kívül az amputáción átesett betegeket támogató szociális háló, családtagok és barátok vegyék körül, akik hozzásegítik ôket a megváltozott állapothoz történô alkalmazkodáshoz és a rehabilitáció sikerességéhez.

Az amputált betegek megküzdési stratégiáit vizsgálva azt látjuk, hogy az egészséges kontrollcsoporthoz képest háttérbe szorul, jelentôs mértékben elmarad a problémaelemzés, a céltudatos cselekvés, valamint az érzelmi egyensúly keresése, ami együtt jár azzal, hogy a kezdeti idôszakban az amputációt követô elsố hónapban csökken a társas támogatás, a reziliencia mértéke alacsonyabb, és ezzel együtt a depresszió tünetegyüttesé, a negatív érzelmi beállítódásé magasabb. A jelenség részben magyarázható a megváltozott élethelyzettel, a visszahúzódott állapottal és a társas programokba való bekapcsolódás fizikai és pszichés nehézségeivel. A társas kapcsolatok a páciensek számára fontos támaszt jelenthetnek, azonban Desmond és MacLachlan (2005) nyomán érdemes megjegyezni, hogy a hasznos és helyénvaló, valamint a túlzottan aggodalmaskodó támogatás között is érdemes különbséget tenni. Míg a társas támogatás protektív tényezôként van jelen a megküzdésben, a páciensben felerôsödhet a tehetetlenség érzése, ha a rokonok, hozzátartozók alábecsülik a beteg képességeit, és válaszreakcióként megjelenhet a visszahúzódás. Az adekvát segítségnyújtásnak mindig a beteg konkrét állapotához, kéréséhez kell igazodnia a megtartott kompetenciák elismerésével. Az amputált betegek megküzdési stratégiáit vizsgálva tehát azt látjuk, hogy a segítségkérés és a problémaelemzés kevésbé jellemzô rájuk a csonkolást követố elsố hónapban, mely tényezôk egyébként a rezilienciával pozitívan korrelálnak. Továbbá mindkét mérési idôpontban pozitív összefüggést mutat a rezilienciával a céltudatos cselekvés és az alkalmazkodás, mely tényezôk szintén elôsegítik a sikeres alkalmazkodást. Az érzelmi indíttatású cselekvés ugyancsak kapcsolatban áll a rezilienciával, azonban - a csonkolást követô hatodik hónap után is - veszélyeztetô tényezóként van jelen, ami rontja a beteg megküzdését. A korábbi szakirodalom is alátámasztja, 
hogy vannak olyan maladaptív megküzdési stratégiák, amelyek egyértelmúen rontják a rehabilitáció sikerességét és a beteg megküzdését az új élethelyzettel (Andersson és Deigham, 2006). A maladaptív stratégiákban az a közös, hogy rontják a betegek fizikai és pszichés jóllétét, ami végül szorongáshoz és további fizikai vagy pszichés tünetekhez vezet. Ilyen stratégia például a szociális értelemben vett visszahúzódás vagy tagadás. A megküzdési stratégiák tehát jelentôs szerepet játszanak a pszichoszociális adaptáció folyamatában, többek között a protézishez való alkalmazkodásban, ami a rehabilitáció sikerességének egyik meghatározója (Whyte és Niven, 2001).

\section{KÖVETKEZTETÉS}

Masten és Powell (2003) szerint a rezilienciakutatások azt az új nézópontot hozták magukkal, hogy felismerjük, a fenyegetô körülmények ellenére miképpen jöhet létre a sikeres alkalmazkodás. Kutatásunk az eddig megjelent azon kevés számú vizsgálatok közé tartozik, amelyek középpontjában a diabetes mellitus szövôdménye miatt alsóvégtag-amputált betegek pszichoszociális vizsgálata áll. Vizsgálatunk a reziliencia nézôpontján keresztül új összefüggésben keresi a traumán átesett páciensek megváltozott fizikai állapotához történô alkalmazkodásának protektív és veszélyeztetô tényezôit, amelyek fontos szerepet játszanak a sikeres adaptáció és a mentális egészség megtartásának szempontjából. Fél évvel az amputációt követôen a betegek problémára irányuló megküzdési stratégiát kezdenek el használni, a céltudatos cselekvés, valamint a problémaelemzés válik dominánssá. A problémára irányuló konfliktusmegoldó stratégia pozitív kapcsolatban áll a rezilienciával, különösképpen az alkalmazkodás és a céltudatos cselekvés; ezzel szemben az érzelemorientált megküzdési stratégia alkalmazása, ezen belül pedig az érzelmi indíttatású cselekvés hátráltatni fogja a betegek sikeres adaptációját. Továbbá veszélyeztetô faktoroknak bizonyult a depresszió és a negatív érzelmek magasabb mértéke. Az olyan protektív tényezôk, mint a pozitív érzelmek, a társas támasz pozitív összefüggést mutatnak a rezilienciával, és ezáltal fontos szerepet játszanak a sikeres megküzdésben. Vizsgálatunk segítségével jól elkülöníthetô az amputált betegcsoport a cukorbeteg és az egészséges kontrollcsoporttól az idôi faktort figyelembe véve. Hat hónappal az amputációt követôen az amputált betegcsoportnak nô a lelki ellenálló képessége, dominánsabbá válnak a pozitív érzelmek, és ezzel együtt a depresszív tünetegyüttes csökken.

Az amputált betegek rehabilitációjának elsôdleges célja a pszichés jóllét helyreállítása, mely kulcspontja a testi fogyatékkal élô személyeknek. Bhuvanesvar és mtsai (2007) hangsúlyozzák a rehabilitációs menetrend jelentôségét, amely már a mútét elôtti idôszakban elkezdôdik. Közvetlenül a csonkolást követôen a rehabilitáció a fájdalom kezelését, a pszichés támogatást, a kötözés és a varratok vizsgálatát helyezi fókuszba. A pszichológus feladata, hogy a team tagjaként elôsegítse a beteg adaptív alkalmazkodását az új élethelyzethez. Az elfogadást erôsíti a betegek és a hozzátartozók edukációja, felkészítése. A cukorbetegségben érintett páciensnek szükséges felhívni a figyelmét a diabétesz egész testet érintő természetére és a helyes egészség-magatartás rendkívüli fontosságára (rendszeres diéta, testgyakorlatok, bórápolás). Az amputált betegek lelki ellenálló képességének javítására irányuló eszközök az individuális pszichoterápia, 
pszichofarmakológiai kezelés, pozitív megküzdési stílusok kialakítása. A kognitív viselkedéses intervenciók jótékony hatással bírnak az amputált betegek azon képességére, hogy pozitívan keretezzék át az amputációt. Oaksford, Frude és Cuddihy (2005) megerôsítik, hogy a rehabilitáció egyik feladata, hogy a beteg képes legyen a megküzdési stratégiákat a stresszes szituáció jellegzetességeihez illeszteni. Emellett a rehabilitáció egy folyamat, amely nem ér véget az osztályon, szükséges a beteg rendszeres utánkövetése (Kullman, Belicza és László, 1997).

\section{LIMITÁCIÓ}

Az amputált betegekkel történó kapcsolatfelvétel és utánkövetésük nagy kihívást és erôfeszítést jelent, azonban kutatócsoportunk szorgalmazza a mintavétel bôvítését, ami a differenciáltabb megértést teszi lehetôvé. Az alkalmazott mintával kapcsolatos limitációban szeretnénk megjegyezni, hogy a csoportok létszámát a jövóben érdemes lenne bóvíteni, hogy a nagyobb elemszámmal további statisztikai elemzéseket végre lehessen hajtani. Az egészséges kontrollcsoport esetében ez azért is kívánatos lenne, mivel a jelen minta egy része kórházi dolgozókból tevődött össze. A kontrollcsoportok kialakításában az egészséges kontrollcsoport mellett beteg kontrollcsoportot is létrehoztunk. A beteg kontrollcsoport kiválasztásában úgy döntöttünk, hogy azon beteganyag illeszkedik legjobban az amputált lábú cukorbetegekhez, akik teljesítik azokat a kritériumokat, hogy szintén diabetes mellitusban szenvednek, rendelkeznek már minimum egy szövôdménnyel, emellett inzulint kapnak, valamint gondozás alatt állnak. A cukorbeteg kontrollcsoport további jellemzóje volt, hogy a betegek többsége hosszú ideje jelen van az egészségügyi ellátó rendszerben, és számos kezelést kapott, melyek célja a további, súlyosabb tünetek megelőzése volt. A késôbbiekben egy olyan cukorbeteg kontrollcsoportot is szeretnénk kialakítani, akik frissen diagnosztizáltak, nem rendelkeznek szövôdménnyel, és nem állnak még gondozás alatt. Úgy véljük, a több típusú minta összehasonlítása differenciáltabb eredményekhez és megközelítéshez vezethet a jövóben. Emellett a tágabb perspektíva érdekében célszerú lenne az utánkövetés idôtartamát növelni, és longitudinális vizsgálatban követni a betegek alkalmazkodóképességét, életminôségét. A korlátok között szeretnénk azt is jelezni, hogy a beteg kontrollcsoport és egészséges kontrollcsoport esetében nem volt utánkövetés. A limitációban továbbá szükséges megjegyeznünk, hogy az amputált betegeket a mútét elôtti idôszakban nem vizsgáltuk, ez némiképpen torzíthatja a vizsgált depresszió konstruktumot. Jelen vizsgálatban nem kizárható az sem, hogy a kimutatott csoportközi különbségeket és a kapcsolatokat egyes, az elemzésbe nem bevont ún. harmadik változók magyarázzák (pl. diabétesz fennállásának ideje vagy akár korábban már meglévố pszichiátriai betegségek). Továbbá szeretnénk hangsúlyozni, hogy a kimutatott kapcsolatokból nem vonhatunk le ok-okozati következtetéseket, ezek együttjárásokat jeleznek mindkét adatfelvételi idôpontban. 


\section{KÖSZÖNETNYILVÁNÍTÁS}

A projekt az Európai Unió támogatásával, az Európai Szociális Alap társfinanszírozásával valósul meg (EFOP-3.6.1.-16-2016-00004 - Átfogó fejlesztések a Pécsi Tudományegyetemen az intelligens szakosodás megvalósítása érdekében).

\section{IRODALOM}

Andersson, M., \& Deigham, F. (2006). Coping strategies in conjunction with amputation - a literature study. Division for health and care Sciences, Karlstads University.

Beck, A. T., Ward, C. H., Mendelson, M., Mock, J., \& Erbaugh, J. (1961). An inventory for measuring depression. Archives of General Psychiatry, 4, 561-571.

Bennett, J. (2016). Limb Loss: The Unspoken Psychological Aspect. Journal of Vascular Nursing, 34(4), 128-130.

Berkman, L. F. (1995). The role of social relations in health promotion. Psychosomatic Medicine, 57(3), 245-254.

Bhuvanesvar, C. G., Epstein, L. A., \& Stern, T. A. (2007). Reactions to amputation: Recognition and treatment. Primary Care Companion to the Journal of Clinical Psychiatry, 9(4), 303-308.

Block, J. H., \& Block, J. (1980). The role of ego-control and ego-resiliency in the origination of behavior. In Collings, W. A. (Ed.), The Minnesota Symposia on Child Psychology (pp. 39-101.). Vol. 13. Hillsdale: Erlbaum.

Boutoille, D., Feraille, A., Maulaz, D., \& Krempf, M. (2008). Quality of life with diabetes-assoicated foot complications: comparison between lower-limb amputation and chronic foot ulceration. Foot E $\mathcal{E}$ Ankle International, 29(11), 1074-1078.

Campbell-Sills, L., \& Stein, M. B. (2007). Psychometric analysis and refinement of the ConnorDavidson Resilience Scale (CD-RISC): Validation of a 10-item measure of resilience. Journal of Traumatic Stress, 20(6), 1019-1028.

Carrington, A., Mawdsley, M., Kincey, J., \& Boulton, A. (1996). Psychological status of diabetic people with or without lower limb disability. Diabetes Research and Clinical Practice, 32(1-2), $19-25$.

Cobb, S. (1976). Social Support as a Moderator of Life Stress. Psychosomatic Medicine, 38(5), 300-314.

Coffey, L., Gallagher, P., \& Horgan, O. (2009). Psychosocial adjustment to diabetes-related lower limb amputation. Diabetes Medicine, 26(10), 1063-1067.

Coker, A. L., Smith, P. H., Thompson, M. P., Mckeown, R. E., Bethea, L., \& Davis, K. E. (2002). Social support protects against the negative effect of partner violence on mental health. Journal of Women's Health Eं Gender-Based Medicine, 11(5), 465-476.

Connor, K. M., \& Davidson, J. R. (2003). Development of a new resilience scale: the ConnorDavidson resilience scale (CD-RISC). Depression and Anxiety, 18(2), 76-82.

Crawford, C. S. (2002). From pleasure to pain: The role of the MPQin the language of phantom limb pain. Social Science E Medicine, 69(5), 655-661.

Desmond, D. M., \& MacLachlan, M. (2002). Psychosocial issues in the field of prosthetics and orthotics. Journal of Prosthetics and Orthotics, 14(1), 19-22.

Desmond, D. M., \& MacLachlan, M. (2005). Coping strategies as predictors of psychosocial adaptation in a sample of elderly veterans with acquired lower limb amputations. Social Science E्F Medicine, 62(1), 208-216. 
Dunn, D. (1996). Well-being following amputation: Salutary effects of positive meaning, optimism and control. Rehabilitation Psychology, 41(4), 245-302.

Dunn, D. S., Uswatte, G., \& Elliot, T. R. (2009). Happiness, Resilience, and Positive Growth Following Physical Disability: Issues for Understanding, Research, and Therapeutic Intervention. In Lopez, S. J., \& Snyder, C. R. (Eds), Oxford handbook of positive psychology (pp. 651-664). 2nd edition. New York: Oxford University Press.

Eisner, C., Darlington, A. S. E., Stride, C. B., \& Grimer, R. (2001). Quality of life implications as a consequence of surgery: limb salvage, primary and secondary amputation. Sarcoma, 5(4), 189-195.

Feeney, S. L. (2001). The relationship between pain and negative affect in older adults: anxiety as a predictor of pain. Anxiety Disorders, 18(6), 733-744.

Fisher, K., \& Hanspal, R. S. (1998). Phantom pain, anxiety, depression, and their relation in consecutive patients with amputated limbs: Case reports. British Medical Journal, 316(7135), 903-904.

Folkman, S., \& Lazarus, R. S. (1980). An analysis of coping in a middleaged community sample. Journal of Health E् Social Behavior, 21(3), 219-239.

Folkman, S., \& Lazarus, R. (1988). Manual for the Ways of Coping questionnaire. Palo Alto, CA: Consulting Psychologists Press.

Fosse, S., Hartemann, H. A., Jacqueminet, S., Ha Van, G., Grimaldi, A., \& Fagot, C. A. (2009). Incidence and characteristics of lower limb amputations in people with diabetes. Diabetes Medicine, 26(4), 391-396.

Fredrickson, B. L., Tugade, M. M., Waugh, C. E., \& Larkin, G. R. (2003). What good are positive emotions in crisis? A prospective study of resilience and emotions following the terrorist attacks on the United States on September 11th, 2001. Journal of Personality $\mathcal{E}$ Social Psychology, 84(2), 365-376.

Gyollai, Á., Simor, P., Köteles, F., \& Demetrovics, Zs. (2011). The psychometric properties of the Hungarian version of the short Positive and Negative Affect Scale (PANAS). Neuropsychopharmacologia Hungarica, 13(2), 73-79.

Hawamdeh, Z. M., Othman, Y. S., \& Ibrahim, A. I . (2008). Assessment of anxiety and depression after lower limb amputation in Jordanian patients. Neuropsychiatric Disease and Treatment, $4(3), 627-633$.

Horgan, O., \& MacLachlan, M. (2004). Psychosocial adjustment to lower-limb amputation: a review. Disability and Rehabilitation, 26(14-15), 837-850.

Horowitz, M. J. (1993). Pathological grief: diagnosis and explanation. Psychosomatic Medicine, 55(3), 260-273.

Horowitz, M. J., Siegel, B., Holen, A., Bonanno, G. A, Milbrath, C. \& Stinson, C. H. (1997). Diagnostic criteria for complicated grief disorder. American Journal of Psychiatry, 154(7), 904-910.

Járai R., Vajda D., Hargitai R., Nagy L., Csókási K., \& Kiss E. Cs. (2015). A Connor-Davidson Reziliencia Kérdôív 10 itemes változatának jellemzôi. Alkalmazott Pszichológia, 15(1), 129-136.

Klohnen, E. C. (1996). Conceptual analysis and measurement of the construct of ego-resiliency. Journal of Personality and Social Psychology, 70(5), 1067-1079.

Kopp M. (1994). Orvosi pszichológia. Budapest: SOTE Magatartástudományi Intézet.

Kullman L., Belicza É., \& László G. (1997). Az alsóvégtag amputáció kétéves eredményei Magyarországon, országos adatbázis alapján. Orvosi Hetilap, 138, 2327-2332.

Livingstone, W., Van De Mortel, T. F., \& Taylor, B. (2011). A path of perpetual resilience: exploring the experience of a diabetes-related amputation through grounded theory. Contemporary Nurse, 39(1), 20-30. 
Livneh, H., Antonak, R. F., \& Gerhardt, J. (1999). Psycholocial adaptation to amputation: the role of sociodemographic variables, disability related factors and coping strategies. International Journal of Rehabilitation, 22(1), 21-31.

Livneh, H., Antonak, R. F., \& Gerhardt, J. (2000). Multidimensional investigation of the structure of coping among people with amputation. Psychosomatics, 41(3), 235-244.

Makó SZ. H., Bernáth L., Makó Sz. N., Veszprémi B., Vajda D., \& Kiss E. Cs. (2016). A MOS SSS - társas támasz mérésére szolgáló kérdốív magyar változatának pszichometriai jellemzôi. Alkalmazott Pszichológia, 16(3), 145-162.

Masten, A. S., \& Powell, J. L. (2003). A Resilience Framework for Research, Policy, and Practice. In Luthar, S. S. (Ed.), Resilience and Vulnerability: Adaptation in the Context of Childhood Adversities (pp. 1-28.). New York: Cambridge University Press.

Masten, A. S. (2001). Ordinary Magic: Resilience Processes in Development. American Psychologist, 56(3), 227-238.

Mayer Á., \& Pénzesné R. Á. (2002). Traumás amputáltak rehabilitációja. Mozgásterápia, 11(1), $15-19$.

McDonald, S., Sharpe, L. \& Blaszczynski, A. (2014). Research: educational and psychological issues the psychosocial impact associated with diabetes-related amputation. Diabetes Medicine, 31, 1424-1430.

Murray, C. D., \& Fox, J. (2002). Body image and prosthesis satisfaction in the lower limb amputee. Disability and Rehabilitation, 24(17), 925-931.

Nikolajsen, L., \& Lindvig, M. (2001). Phantom pain after amputation of extremities. Ugeskr Laeger, 163(24), 3338-3341.

Oaksford, K., Frude, N., \& Cuddihy, R. (2005). Positive coping and stress-related psychological growth following lower limb amputation. Rehabilitation Psychology, 50(3), 266-277.

Panyi, L. K., \& Lábadi, B. (2015). Pszichológiai alkalmazkodás alsóvégtag-amputációt követôen. Orvosi Hetilap, 156(39), 1563-1568.

Pereira B. P., Kour A. K., Leow E. L., \& Pho, R. W. H. (1996). Benefits and use of digital prostheses. Journal of Hand Surgery, 21(2), 222-228.

Peters, E. J. G., Childs, M. R., Wunderlich, R. P., Harkless, L. B., Armstrong, D. G., \& Lavery, L. A. (2001). Functional status of persons with diabetesrelated lower-extremity amputations. Diabetes Care, 24(10), 1799-1804.

Pollini, I., \& Golant, S. K. (1994). Taking charge: Overcoming the challenges of long-term illness. New York: Random House.

Prigerson, H. G., \& Vanderwerker, L. C. (2005). Final Remarks. Omega, 52(1), 91-94.

Prigerson, H. G., Horowitz, M. J., Jacobs, S. C., Parkes, C. M., Aslan, M. (2009). Prolonged Grief Disorder: Psychometric Validation of Criteria Proposed for DSM-V and ICD11. PLOS Medicine, 6(8), e1000121.

Price, E. M., \& Fisher, K. (2002). How does counseling help people with amputation? Journal of Prosthetics and Orthotics, 14(3), 102-106.

Racy, J. C. (1989). Psychological aspects of amputation. In Moore, W. S., \& Malone J. M. (Eds), Lower Extremity Amputation (pp. 330-340). Philadelphia: Saunders.

Rajiv, S., Hunter, J., \& Alistair, P. (2007). The rapid resolution of depression and anxiety symptoms after lower limb amputation. Clinical Rehabilitation, 21(8), 754-759.

Reed-Victor, E. \& Stronge, J. H. (2002). Homeless students and resilience: staff perspectives on individual and environmental factors. Journal of Children E Poverty, 8(2), 159-183.

Regöly-Mérei J. (2002). A nem traumás eredetú amputációkról. Mozgásterápia, 11, 3-6.

Ridder, D. de, Geenen, R., Kuijer, R., \& Middendorp V. (2008). Psychological adjustment to chronic disease. The Lancet, 372(9634), 246-255. 
Rózsa S., Szádóczky E., \& Füredi J. (2001). A Beck Depresszió Kérdôív rövidített változatának jellemzối hazai mintán. Psychiatria Hungarica, 16(4), 384-402.

Rózsa, S., Purebl, Gy., Susánszky, É. (2008). Dimensions of coping: Hungarian adaptation of the Ways of Coping Questionnaire. [A megküzdés dimenziói: a Konfliktusmegoldó Kérdôív hazai adaptációja.] Mentálhigiéné és Pszichoszomatika, 9(3), 217-241.

Rybarczyk, B., Nyenhuis, D. L., Nicholas, J. J., Cash, S. M., \& Kaiser, J. (1995). Body image, percieved social stigma, and the prediction of psychosocial adjustment to leg amputation. Rehabilitation Psychology, 40(2), 95-110.

Séguin, L., Potvini, L., Denis, M., \& Loiselle, J. (1995). Chronic stressors, social support, and depression during pregnancy. Obstetrics E Gynecology, 85, 583-589.

Sherbourne, D. C., \& Stewart, A. L. (1991). The MOS Social Support Survey. Social Science E Medicine, 32(6), 705-714.

Singh, R., Ripley, D., Pentland, B., Todd, I., Hunter, J., Hutton, L., \& Philip, A. (2009). Depression and anxiety symptoms after lower limb amputation: the rise and fall. Clinical Rehabilitation, 23(3), 281-286.

Till A. (2010). Amputáció és rehabilitáció idôskorban. Családorvosi Fórum, 2, 28-30.

Uchino, B. N., Cacioppo, J. T. \& Kiecolt-Glaser, J. K. (1996). The Relationship Between Social Support and Physiological Processes: A Review With Emphasison Underlying Mechanisms and Implications for Health. Psychological Bulletin, 119(3), 488-531.

Walsh, B. K. (2006). Grief and loss: Theories and skills for helping professionals. Boston, Mass: Pearson Allyn \& Bacon.

Walsh, M. V., Amstrong, T. W., Poritz, J., Elliott, T. R., Jackson, W. T. \& Ryan, T. (2016). Resilience, Pain Interference, and Upper Limb Loss: Testing the Mediating Effects of Positive Emotion and Activity Restriction on Distress. Archives of Physical Medicine, 97(5), 781-787.

Washington J. (2013). The Relations among Psychological and Demographic Factors in Individuals with Lower Limb Amputation. Senior Theses, Trinity College. Hartford: CT Trinity College Digital Repository.

Watson, D., Clark, L. A., \& Tellegen, A. (1988). Development and validation of brief measures of positive and negative affect: The PANAS Scales. Journal of Personality and Social Psychology, 54(6), 1063-1070.

Werner, E., \& Smith, R. S. (1992). Overcoming the odds: High risk children from birth to adulthood. Ithaca, NY: Cornell University Press.

Whyte, A., \& Niven, C. A. (2001). Psychological distress in amputees with phantom limb Pain. Journal of Pain and Symptom Management, 22(5), 938-946.

Williamson, G. M. (1998). The central role of restricted normal activities in adjustment to illness and disability: A model of depressed affect. Rehabilitation Psychology, 43(4), 327-347.

Willrich, A., Pinzur, M., McNeil, M., Juknelis, D., \& Lavery, L. (2005). Health related quality of life, cognitive function, and depression in diabetic patients with foot ulcer or amputation. A preliminary study. Foot $\mathcal{E}$ Ankle International, 26(2), 128-134.

Wolfelt, A. (1991). Toward an understanding of complicated grief: a comprehensive overview. American Journal of Hospice and Palliative Medicine, 8(2), 28-30.

Wolin, S. J., \& Wolin, S. (1993). Bound and Determined: Growing up resilient in a troubled family. New York: Villard. 


\title{
RESILIENCE IN DIABETIC PATIENTS WITH LOWER LIMB AMPUTATION
}

\author{
MAKAI, GÁBOR - BANDI, SZABOLCS - KISS, ENIKŐ CSILLA
}

Background and aims: Amputation is a traumatic experience that alters amputees' views on themselves and their environment. The present study focused on the psychological, social and physical challenges amputees have to face after the intervention, and on the coping strategies they employ in this critical situation. Adopting a resilience-based approach, we aimed to reveal those protective and risk factors that would influence patients' adaptive capacity and mental well-being in the long term.

Method: A test battery compiled by our research team was administered to lower-limb amputees with diabetes mellitus $(n=46)$ in the first and sixth month after amputation. Amputees were compared to healthy control participants $(N=63)$ and patients with type 2 diabetes $(N=54)$. The test battery included the Beck Depression Inventory (BDI-R), the Connor-Davidson Resilience Scale (CD-RISC), the Medical Outcomes Study Social Support Survey (MOS-SSS), the Positive and Negative Affect Schedule (PANAS), and the Ways of Coping Questionnaire (WOC).

Results: Patients' depression symptoms and negative emotions showed a significant decrease in the sixth month after amputation. At the same time, positive emotions and resilience became predominant. Patients' need for social support and especially for positive social interactions increased over time and showed a positive relationship with resilience. Furthermore, the coping strategies of purposeful activity and adaptation were found to serve as protective factors, whereas negative emotional experiences impaired patients' adaptive coping.

Conclusions: Patients with higher levels of resilience cope with difficulties more efficiently than those employing negative adaptation strategies.

Keywords: resilience, diabetes-related lower limb amputation, depression, anxiety, coping, protective and risk factors

A cikk a Creative Commons Attribution 4.0 International License (https://creativecommons. org/licenses/by/4.0) feltételei szerint publikált Open Access közlemény, melynek szellemében a cikk bármilyen médiumban szabadon felhasználható, megosztható és újraközölhetô, feltéve, hogy az eredeti szerzô és a közlés helye, illetve a CC License linkje és az esetlegesen végrehajtott módosítások feltüntetésre kerülnek. (SID_1) 